\title{
Response of Onion Yield and Its Chemical Content to NPK Fertilization and Foliar Application of Some Micronutrients
}

\section{Karim Fikry Fouda}

Soils Department, Faculty of Agriclture, Mansoura University, Monsoura, Egypt

\begin{abstract}
7 HE PRESENT study was conducted at the Experimental Farm of the Faculty of Agric., Mansoura University. Six treatments were arranged in Randomized Complete Block Design with three replications as follows: $50 \%$ and $100 \%$ from the recommended doses (RD) of NPK, $300 \mathrm{Fe} \mathrm{mg} \mathrm{L}{ }^{-1}+50 \%$ from RD of NPK, $50 \mathrm{Cu} \mathrm{mg} \mathrm{L}{ }^{-1}$

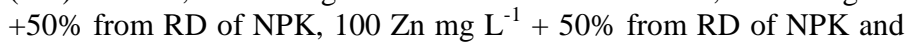
$\mathrm{Fe}+\mathrm{Cu}+\mathrm{Zn}+50 \%$ from RD of NPK. Micronutrients were added as foliar application while NPK as soil addition. Obtained results indicated that all treatments under investigation significantly affected all traits. The highest values of vegetative growth parameters including fresh, dry weight of bulb and total yield as well as N, P, K, Cu, Fe and $\mathrm{Zn}$, beside nitrate reductase activity in onion bulb recorded with using $50 \%$ NPK as soil addition and foliar application of $(\mathrm{Fe}+\mathrm{Zn}+\mathrm{Cu})$. $\mathrm{NO}_{3}-\mathrm{N}$ and $\mathrm{NO}_{2}$-Nin onion bulb also recorded the highest mean values with the untreated plant (control). The highest availability values of $\mathrm{N}$, $\mathrm{P}$ and $\mathrm{K}$ in the soil after harvesting were recorded in case of the addition of $\mathrm{Fe}+\mathrm{Cu}+\mathrm{Zn}+50 \% \mathrm{RD}$ from NPK.
\end{abstract}

Keywords: NPK fertilization, Micronutrients, Chemical content, Soil nutrients availability and Onion.

Onion plant (Allium cepa L.) is a species of the Alinaceae family that has a great economic importance and the second most important vegetable crop in the world (FAO, 2006 and Mishra et al., 2013). Onion bulb is a rich source of minerals like phosphorus and calcium. It also contains protein and vitamin C, quercetin and flavonoids. Quercetin helps to eliminate free radicals in the human body, to inhibit low density lipoprotein oxidation (an important reaction in the atherosclerosis and coronary heart disease), to protect and regenerate vitamin $\mathrm{E}$ and to inactivate the harmful effects of chelate metal ions (Scott, 2007). In Egypt, onion ranks fourth after cotton, rice, and citrus as an export crop. The total cultivated area was 36153 fed (15184.3 ha) in 1999 and the total production was 305201 tons (CAPMS, 2000).

Micronutrients are just as important as the macronutrients in respect of their functions in plants. The micronutrients required by plants include iron $(\mathrm{Fe})$, zinc $(\mathrm{Zn})$ and copper $(\mathrm{Cu})$. Availability of micronutrients (except Mo) generally decreases as soil $\mathrm{pH}$ increases. Therefore, availability of $\mathrm{Zn}, \mathrm{Mn}$ and $\mathrm{Cu}$ declines rapidly as soil $\mathrm{pH}$ rises (Umma, 2012). Although the requirement of a micronutrient is small compared to a macronutrient, nevertheless micronutrient deficiency can limit the crop growth and 
production. Micronutrients have a great role in the fertilizer program to achieve higher and sustainable crop yields. Foliar application of micronutrients such as $\mathrm{Fe}, \mathrm{Zn}, \mathrm{Mn}$ and $\mathrm{B}$ could be beneficial as to prevent nutrient deficiency and to avoid soil problems that affect their availability. Kamel (2001) reported that spraying onion plants with solution containing $300 \mathrm{mg} \mathrm{L}^{-1}$ of micronutrients chelate (Fe-EDHA, 6\% Fe; Mn-EDTA, 12\% $\mathrm{Mn}$ and $\mathrm{Zn}$-EDTA, $14 \% \mathrm{Zn}$ ) four times significantly increased total yield and total contents of all studied nutrients. El-Tohamy et al. (2009) revealed that essential oil, growth and yield of onion plants significantly increased by the application of $\mathrm{Fe}, \mathrm{Zn}$ and $\mathrm{Mn}$ compared to control plants. The results showed that the high concentration of $\mathrm{Fe}$ and the low concentrations of both $\mathrm{Zn}$ and $\mathrm{Mn}$ had the best effects compared to the other concentrations. Durgude et al. (2013) reported that the highest total uptake of total nitrogen and iron by onion was found in foliar treatment of $0.5 \% \mathrm{FeSO}_{4}$.

Mineral fertilizers are considered to be an important source of macro- and microelements in crop production. Continuous application of mineral fertilizers may adversely affect soil chemical composition, nutrient imbalance, soil degradation and crop yield. Nitrogen, phosphorus and potassium (NPK) are necessary for onion plant growth, maturity, bulb yield and quality. El-Desuki and Sawan (2001) concluded that NPK uptake and bulb quality increased with increasing level of NPK fertilizer up to 132:96:96 kg fed ${ }^{-1}$. $\mathrm{NO}_{3}-\mathrm{N}$ accumulation in the onion bulb gradually and significantly increased with increasing level of NPK fertilizer up to the highest level. Baddour (2014) used recommended dose of NPK which significantly affected the mean values of N, P and $\mathrm{K} \%$ and $\mathrm{Fe}, \mathrm{Zn}$ and $\mathrm{Mn}\left(\mathrm{mg} \mathrm{kg}^{-1}\right)$ as well as $\mathrm{NO}_{3}-\mathrm{N}$ of onion bulb. Shaheen et al. (2007) recorded the highest values of $\mathrm{K}, \mathrm{Fe}, \mathrm{Mn}$ and $\mathrm{Zn}$ as well as the content of total protein, $\mathrm{N}, \mathrm{P}, \mathrm{K}, \mathrm{Mn}$, and $\mathrm{Cu}$ of onion recorded a good positive correlation with the increasing phosphorus levels addition. The present study was undertaken to study the effect of macro- and micro-nutrients on chemical composition of onion and their soil bioavailability.

\section{Materials and Methods}

The present study was conducted at the Experimental Farm of the Faculty of Agric., Mansoura Univ. with 6 treatments arranged in Randomized Complete Block Design with three replications as follows: $50 \%$ and $100 \%$ from recommended doses (RD) of NPK, $50 \%$ from (RD) of NPK $+300 \mathrm{mg} \mathrm{L}^{-1} \mathrm{Fe}, 50 \%$ from (RD) of NPK + $50 \mathrm{mg} \mathrm{L}^{-1}$ $\mathrm{Cu}, 50 \%$ from (RD) of NPK $+100 \mathrm{mg} \mathrm{L}^{-1} \mathrm{Zn}$ and $50 \%$ from (RD) of NPK + mixture of the same rates of $(\mathrm{Fe}+\mathrm{Cu}+\mathrm{Zn})$. Micronutrients were added as foliar application while NPK as soil addition.

The soil texture of the experimental site is clayey (sand: $23.1 \%$, silt: $30.1 \%$ and clay 46.8\%), and having pH: 7.85, EC: $3.91 \mathrm{dS} \mathrm{m}{ }^{-1}, \mathrm{CaCO}_{3}: 3.78 \%$, OM: $1.72 \%$, N:P:K in $\mathrm{mg} \mathrm{L}^{-1} ; 52.1: 5.13: 197$ were determined according to the standard methods reported by van Reeuwijk (2002). The experiment included onion cultivar (Allium cepa L.). Seedlings of the onion were transplanted on January $20^{\text {th }}, 2015$ at distance of $20 \mathrm{~cm}$ apart between the plants on one side of ridges $(70 \mathrm{~cm}$ wide and $5 \mathrm{~m}$ long). The plot consisted of 3 ridges, making an area of about $10 \mathrm{~m}^{2}$. NPK treatment was treated with

Egypt. J. Soil Sci. 56, No.3 (2016) 
90,60 and $48 \mathrm{~kg} \mathrm{fed}^{-1}$ for onion as recommended doses of N, P and K by the Ministry of Agriculture and Soil Reclamation in the form of ammonium sulfate $(20.5 \% \mathrm{~N})$, super phosphate $\left(15 \% \mathrm{P}_{2} \mathrm{O}_{5}\right)$ and potassium sulfate $\left(48 \% \mathrm{~K}_{2} \mathrm{O}\right)$. Full dose of $\mathrm{P}$ was added to the soil before sowing while; $\mathrm{N}$ and $\mathrm{K}$ were added in two equal doses one after 15 days from sowing and the other two weeks later. The application of micronutrients; zinc 100 $\mathrm{mg} \mathrm{L}^{-1}$, iron $300 \mathrm{mg} \mathrm{L}^{-1}$ and copper $50 \mathrm{mg} \mathrm{L}^{-1}$ solution was sprayed 30 and 45 days from sowing. The source of micronutrient for $\mathrm{Zn}, \mathrm{Fe}$ and $\mathrm{Cu}$ were EDTA. Onion handily yielded at $1^{\text {st }}$ week of May and plants were collected in groups to dry for 10 days then onion yield components took place. The following parameters were recorded: fresh and dry weight of bulb (g/plant) and total yield (ton/fed). Elements of $\mathrm{N}, \mathrm{P}, \mathrm{K}$ were determined according to Mertens (2005a, b), $\mathrm{NO}_{3}-\mathrm{N}, \mathrm{NO}_{2}-\mathrm{N}$ and nitrate reductase activity (Singh, 1988) as well as $\mathrm{Fe}, \mathrm{Zn}$ and $\mathrm{Cu}$ (Kumpulainen et al., 1983). Soil availability of N, P and $\mathrm{K}$ were measured in the soil samples after harvesting as reported by Reeuwijk (2002).

Data reported for chemical content of onion plant and soil availability were assessed by analyses of variance (ANOVA), Duncan and the least significant difference (L.S.D) method was used for any significant differences at the $\mathrm{P}<0.05$ levels between the means of treatment values to the methods described by Gomez and Gomez (1984). All the analyses were conducted using software computer CoSTATE.

\section{Result and Discussion}

It is evident from Table 1 that NPK and micronutrient treatments revealed clear significant differences of vegetative growth parameters. The listed data showed that $50 \%$ from $\mathrm{RD}$ of $\mathrm{NPK}+(\mathrm{Fe}+\mathrm{Zn}+\mathrm{Cu})$ treatments recorded the highest values of plant height, fresh and dry weight of onion plant foliage comparing with the control treatment without adding any fertilization. The rate of the increasing was $33.44,30.57$ and $30.95 \%$ for plant height, fresh and dry weight, respectively. These results indicated that $(\mathrm{Fe}+\mathrm{Zn}$ $+\mathrm{Cu}$ ) micronutrients when used with NPK fertilizers interaction supplied plant nutrients and provided, better growing conditions which helped for getting proper vegetative growth.

The increase in yield might be due to applying nitrogen improving the vegetative growth and increase in net assimilation rate and accelerating the photosythates in storage organs of bulbs resulting in an increased diameter and weight of the bulb (Sharma, 1992). In addition, the effect of $P$ and $K$ on growth components could be explained through its roles, which is extremely important as a structural part of many components, notably nucleic acid, and phospholipids. In addition phosphorus plays an indispensable role in energy metabolism; the high energy of hydrolysis of phosphate and various organic phosphate bonds being used to induce chemical reaction. The stimulating effect of NPK combination on the above mentioned characteristics were confirmed by Jilani et al. (2003) who found that NPK doses resulted in the tallest plant height and maximum number of leaves per plant, compared with control treatment (00:00:00 NPK). These results are in harmony with Yaso and Abdel Razzak (2007), Kandil et al. (2013), Kamble \& Kathmale (2015) and El Dardiry et al. (2015).

Egypt. J. Soil Sci. 56, No.3 (2016) 
TABLE 1. Plant height, fresh and dry weight of onion plant foliage as affected by NPK application and some micronutrients

\begin{tabular}{|l|c|c|c|}
\hline Treatments & $\begin{array}{c}\text { Plant height } \\
(\mathbf{c m})\end{array}$ & $\begin{array}{c}\text { Fresh weight } \\
(\text { g/plant })\end{array}$ & $\begin{array}{c}\text { Dry weight } \\
\text { (g/plant })\end{array}$ \\
\hline Control & $45.52 \mathrm{e}$ & $41.54 \mathrm{e}$ & $3.49 \mathrm{e}$ \\
\hline $50 \%$ from RD of NPK & $49.04 \mathrm{~d}$ & $43.80 \mathrm{~d}$ & $3.69 \mathrm{~d}$ \\
\hline $100 \%$ from RD of NPK & $58.29 \mathrm{~b}$ & $52.06 \mathrm{~b}$ & $4.39 \mathrm{~b}$ \\
\hline $\begin{array}{l}50 \% \text { from RD of NPK+ Fe 300 } \\
\text { ppm }\end{array}$ & $55.41 \mathrm{c}$ & $49.49 \mathrm{c}$ & $4.17 \mathrm{c}$ \\
\hline $\begin{array}{l}50 \% \text { from RD of NPK+ Cu 50 } \\
\text { ppm }\end{array}$ & $50.61 \mathrm{~d}$ & $45.20 \mathrm{~d}$ & $3.81 \mathrm{~d}$ \\
\hline $\begin{array}{l}50 \% \text { from RD of NPK+ Zn } 100 \\
\text { ppm }\end{array}$ & $53.49 \mathrm{c}$ & $47.77 \mathrm{c}$ & $4.03 \mathrm{c}$ \\
\hline $\begin{array}{l}50 \% \text { from RD of NPK+ } \\
\text { Fe+Zn+Cu) }\end{array}$ & $60.74 \mathrm{a}$ & $54.24 \mathrm{a}$ & $4.57 \mathrm{a}$ \\
\hline \multicolumn{1}{|c|}{ LSD at 5\% } & $\mathbf{2 . 2 5}$ & $\mathbf{2 . 0 1}$ & $\mathbf{0 . 1 7}$ \\
\hline
\end{tabular}

The increase in yield by mixing of micronutrients as $\mathrm{Cu}, \mathrm{Zn}$ and $\mathrm{Fe}$ might be due to it is essential for plant metabolism; it is one of the constituents of certain oxidizing reduction enzyme, therefore, its role in plant metabolism and participation in oxidation-reduction action. It checks certain diseases and improves the growth of plant. As for zinc, El Gamelli (2000), Bose et al. (2009) and Alam et al. (2010) stated that the plant height and fresh weight of leaves were positively affected by application of micronutrients. Fresh, dry weight and total yield of onion plant as affected by application of NPK and microelements were represented in Table 2 . The resulted data mentioned that the highest values were recorded at $50 \%$ from $\mathrm{RD}$ of $\mathrm{NPK}+(\mathrm{Fe}+\mathrm{Zn}+\mathrm{Cu})$ comparing with using the control with no addition which recorded the lowest values of the mentioned parameters. The increase in yield might be due to applying nitrogen which improving the vegetative growth and increase in net assimilation rate and accelerating the photosythates in storage organs of bulbs resulting in an increased diameter and weight of the bulb (Sharma, 1992). This results were in harmony with Yaso \& Abdel Razzak (2007), Kandil et al. (2013), Kamble and Kathmale (2014) and El Dardiry et al. (2015), they found that Giza 20, Giza Red and Texas Early Yellow Grano X Giza 20 cultivars were significantly better in most of the studied characters in both seasons. They also added that, mineral fertilization of onion with $214.2 \mathrm{~kg} \mathrm{~N}+71.4 \mathrm{~kg} \mathrm{P}_{2} \mathrm{O}_{5}+57.1 \mathrm{~kg} \mathrm{~K}_{2} \mathrm{O}$ ha $^{-1}\left(85.7 \mathrm{~N}, 28.6 \mathrm{P}_{2} \mathrm{O}_{5}\right.$, $22.8 \mathrm{~K}_{2} \mathrm{O} \mathrm{kg} \mathrm{fed} \mathrm{f}^{-1}$, in same sequences) surpassed other studied fertilization treatments and resulted in highest values of most studied characters in both seasons. 
TABLE 2. Fresh, Dry weight of bulb and total yield as affected by NPK application and some micronutrients

\begin{tabular}{|l|c|c|c|}
\hline \multicolumn{1}{|c|}{ Treatments } & $\begin{array}{c}\text { Fresh weight } \\
\text { of bulb } \\
\text { (g/plant) }\end{array}$ & $\begin{array}{c}\text { Dry weight } \\
\text { of bulb } \\
\text { (g/plant) }\end{array}$ & $\begin{array}{c}\text { Total } \\
\text { yield } \\
\text { (ton/fed) }\end{array}$ \\
\hline Control & $113.54 \mathrm{e}$ & $10.12 \mathrm{e}$ & $8.02 \mathrm{e}$ \\
\hline $50 \%$ from RD of NPK & $116.67 \mathrm{~d}$ & $13.13 \mathrm{~d}$ & $10.34 \mathrm{~d}$ \\
\hline $100 \%$ from RD of NPK & $138.68 \mathrm{~b}$ & $15.61 \mathrm{~b}$ & $12.29 \mathrm{~b}$ \\
\hline $50 \%$ from RD of NPK+ Fe 300 ppm & $131.83 \mathrm{c}$ & $14.84 \mathrm{c}$ & $11.68 \mathrm{c}$ \\
\hline $50 \%$ from RD of NPK+ Cu 50 ppm & $120.41 \mathrm{~d}$ & $13.55 \mathrm{~d}$ & $10.67 \mathrm{~d}$ \\
\hline $50 \%$ from RD of NPK+ Zn 100 ppm & $127.26 \mathrm{c}$ & $14.32 \mathrm{c}$ & $11.28 \mathrm{c}$ \\
\hline $50 \%$ from RD of NPK+ $\mathrm{Fe}+\mathrm{Zn}+\mathrm{Cu})$ & $144.49 \mathrm{a}$ & $16.26 \mathrm{a}$ & $12.81 \mathrm{a}$ \\
\hline LSD $_{\text {at } 5 \%}$ & $\mathbf{5 . 3 6}$ & $\mathbf{0 . 6 1}$ & $\mathbf{0 . 4 8}$ \\
\hline
\end{tabular}

Data presented in Table 3 showed the interaction effect of soil addition of NPK fertilization and foliar application of micronutrient on $\mathrm{N}, \mathrm{P}$ and $\mathrm{K}$ concentrations and its uptake (Fig. 1) of onion plant comparing with the untreated plants. All present treatment significantly affected N, P and K concentrations and its uptake, using NPK fertilization increased traits with increasing up to $100 \% \mathrm{RD}$. Adding some micronutrients $+50 \% \mathrm{RD}$ increased N, P and K\% and its uptake followed by $100 \%$ NPK. It means that the highest best chemical quality $\mathrm{N}, \mathrm{P}$ and $\mathrm{K} \%$ of onion bulbs was associated with the plants which received 50\% from RD of NPK + mixture of some micronutrients with the levels under study.

This might be attributed to the chemical NPK form with more availability and solubility for plant absorption. Moreover, increasing the levels of NPK in root zone caused an increase in its absorption by plants, consequently increased the ability of plant roots to uptake more nutrients in plant tissues. Many investigators had a good accordance with that which obtained in this script; Diriba-Shiferaw et al. (2014), El Dardiry et al. (2015) and Singh \& Ram (2015).

TABLE 3. Nitrogen, phosphorus and potassium concentration as affected by NPK application and some micronutrients

\begin{tabular}{|l|c|c|c|}
\hline Treatments & $\begin{array}{c}\text { Nitrogen } \\
(\mathbf{\%})\end{array}$ & $\begin{array}{c}\text { Phosphorus } \\
(\boldsymbol{\%})\end{array}$ & $\begin{array}{c}\text { Potassium } \\
(\boldsymbol{\%})\end{array}$ \\
\hline Control & $1.61 \mathrm{~g}$ & $0.165 \mathrm{~g}$ & $1.88 \mathrm{~g}$ \\
\hline $50 \%$ from RD of NPK & $1.87 \mathrm{~d}$ & $0.176 \mathrm{e}$ & $2.03 \mathrm{f}$ \\
\hline $100 \%$ from RD of NPK & $2.23 \mathrm{~b}$ & $0.214 \mathrm{~b}$ & $2.40 \mathrm{~b}$ \\
\hline $50 \%$ from RD of NPK+ Fe $300 \mathrm{ppm}$ & $2.12 \mathrm{c}$ & $0.206 \mathrm{bc}$ & $2.32 \mathrm{c}$ \\
\hline $50 \%$ from RD of NPK+ Cu $50 \mathrm{ppm}$ & $1.93 \mathrm{~d}$ & $0.187 \mathrm{~d}$ & $2.13 \mathrm{e}$ \\
\hline $50 \%$ from RD of NPK+ Zn $100 \mathrm{ppm}$ & $2.04 \mathrm{c}$ & $0.198 \mathrm{c}$ & $2.23 \mathrm{~d}$ \\
\hline $\begin{array}{l}50 \% \text { from RD of NPK+ } \mathrm{Fe}+\mathrm{Zn}+ \\
\mathrm{Cu})\end{array}$ & $2.32 \mathrm{a}$ & $0.225 \mathrm{a}$ & $2.50 \mathrm{a}$ \\
\hline \multicolumn{1}{|c|}{ LSD $_{\text {at } 5 \%}$} & $\mathbf{0 . 0 9}$ & $\mathbf{0 . 0 0 9}$ & $\mathbf{0 . 0 7}$ \\
\hline
\end{tabular}

Egypt. J. Soil Sci. 56, No.3 (2016) 


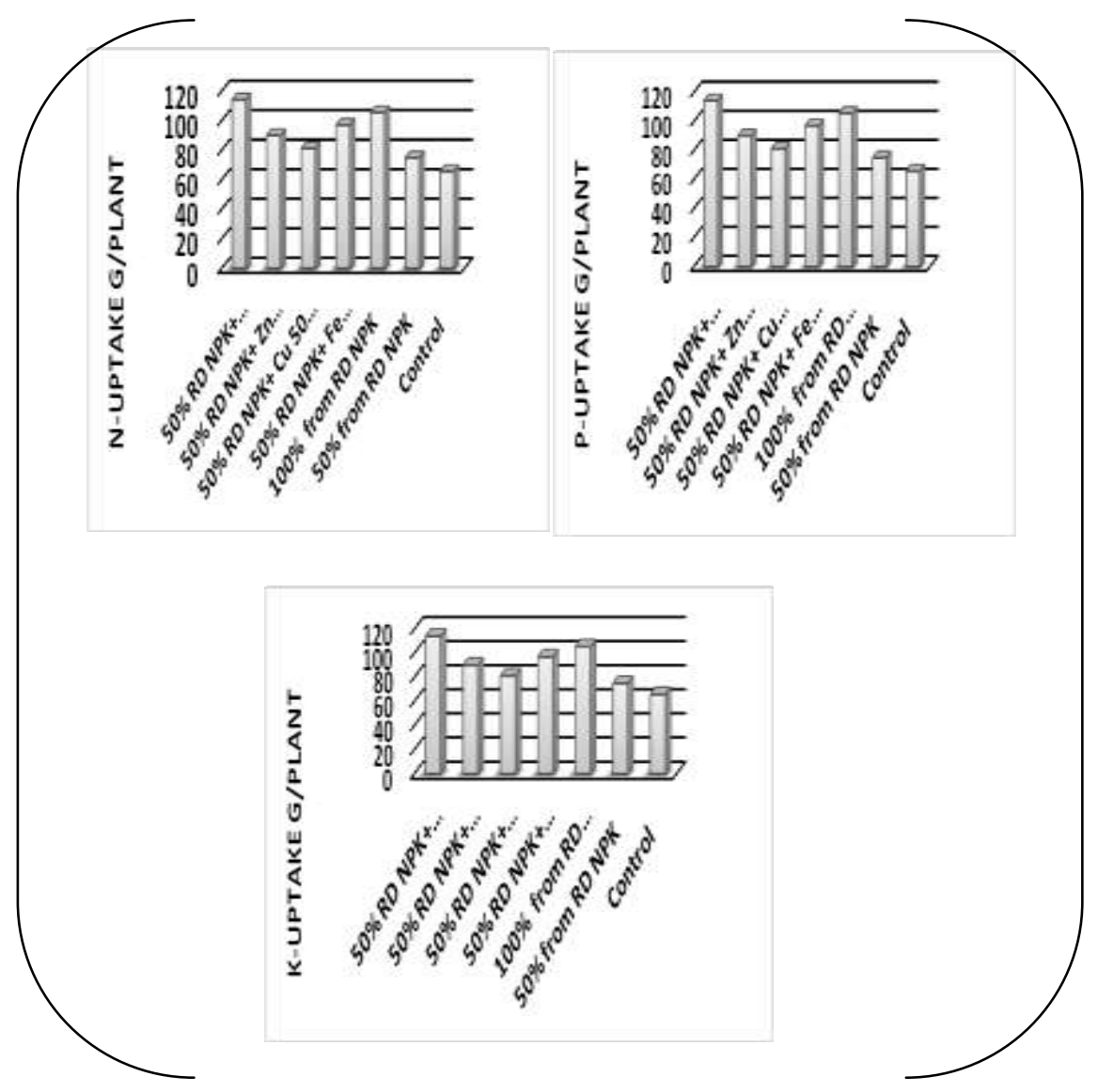

Fig. 1. Nitrogen, phosphorus and potassium uptake g/plant as affected by NPK application and some micronutrient

The results in Table 4 revealed that the effect of all treatments under study significantly affected contents of $\mathrm{Zn}, \mathrm{Fe}$ and $\mathrm{Cu}$ and its uptake mg/plant as illustrated in Fig. 2., in bulb of onion. The contents of $\mathrm{Zn}, \mathrm{Fe}$ and $\mathrm{Cu}$ in bulb onion recorded a good positive correlation with application of NPK and micronutrients. In addition, the differences between adding of all treatments comparing with using NPK in single form and the untreated plants were great enough to be significant at $5 \%$ level. It means that, the best chemical content of onion bulbs was associated with the plants which received $50 \% \mathrm{NPK}$ plus $(\mathrm{Fe}+\mathrm{Zn}+\mathrm{Cu})$.

Significant increases in contents of $\mathrm{Zn}, \mathrm{Fe}$ and $\mathrm{Cu}$ and its uptake in bulb onion due to the foliar application of micronutrients $\mathrm{Fe}, \mathrm{Zn}$ and $\mathrm{Cu}$ confirm that foliar fertilizers are absorbed right at the site where they are used and are effective sources of traits and better nutrient uptake by onion bulb under foliar fertilization.

Egypt. J. Soil Sci. 56, No.3 (2016) 
Zinc, iron and copper contents in onion bulb was maximum in the treatments where $(\mathrm{Fe}+\mathrm{Zn}+\mathrm{Cu})$ was applied with $50 \% \mathrm{NPK}$. Zinc, iron and copper uptake deserves special attention because our soils are deficient in micronutrients and are largely immobile. As a result of limited soil availability, zinc, iron and copper is applied as a foliar spray. Foliar fertilization of crops has been considered a precious supplement to the application of nutrients under adverse soil and environmental situations, low soil nutrients bioavailability, hard top soil, and decreased root activity during the reproductive growth stage of plants (Alkaff and Hassan, 2003). It facilitates timely translocation of deficient nutrients to plant system through leaf tissues (Chattopadhyay et al., 2003). Foliar fertilization enhances nutrient use efficiency of crops (Fageria et al., 2009).

TABLE 4. Zinc, iron and copper content in onion plants as affected by NPK application and some micronutrient

\begin{tabular}{|l|c|c|c|}
\hline Treatments & Zinc $\left(\mathbf{m g ~ L}^{\mathbf{- 1}}\right)$ & Iron $\left(\mathbf{m g ~ L}^{\mathbf{- 1}}\right)$ & $\begin{array}{c}\text { Copper } \\
\left(\mathbf{m g ~ L}^{-\mathbf{1}}\right)\end{array}$ \\
\hline Control & $8.31 \mathrm{~g}$ & $26.01 \mathrm{~g}$ & $2.98 \mathrm{~g}$ \\
\hline $50 \%$ from RD of NPK & $8.54 \mathrm{f}$ & $27.14 \mathrm{f}$ & $3.09 \mathrm{f}$ \\
\hline $100 \%$ from RD of NPK & $8.96 \mathrm{e}$ & $30.64 \mathrm{c}$ & $3.72 \mathrm{c}$ \\
\hline $50 \%$ from RD of NPK+ Fe 300 ppm & $9.36 \mathrm{~d}$ & $32.02 \mathrm{~b}$ & $3.47 \mathrm{~d}$ \\
\hline $50 \%$ from RD of NPK+ Cu 50 ppm & $9.72 \mathrm{c}$ & $29.44 \mathrm{~d}$ & $3.87 \mathrm{~b}$ \\
\hline $50 \%$ from RD of NPK+ Zn 100 ppm & $10.04 \mathrm{~b}$ & $28.30 \mathrm{e}$ & $3.28 \mathrm{e}$ \\
\hline $\begin{array}{l}50 \% \text { from RD of NPK+ } \mathrm{Fe}+\mathrm{Zn}+ \\
\mathrm{Cu})\end{array}$ & $10.45 \mathrm{a}$ & $33.16 \mathrm{a}$ & $4.04 \mathrm{a}$ \\
\hline \multicolumn{1}{|c|}{ LSD $_{\text {at } \mathbf{5 \%}}$} & $\mathbf{0 . 1 5}$ & $\mathbf{0 . 2 0}$ & $\mathbf{0 . 1 1}$ \\
\hline
\end{tabular}

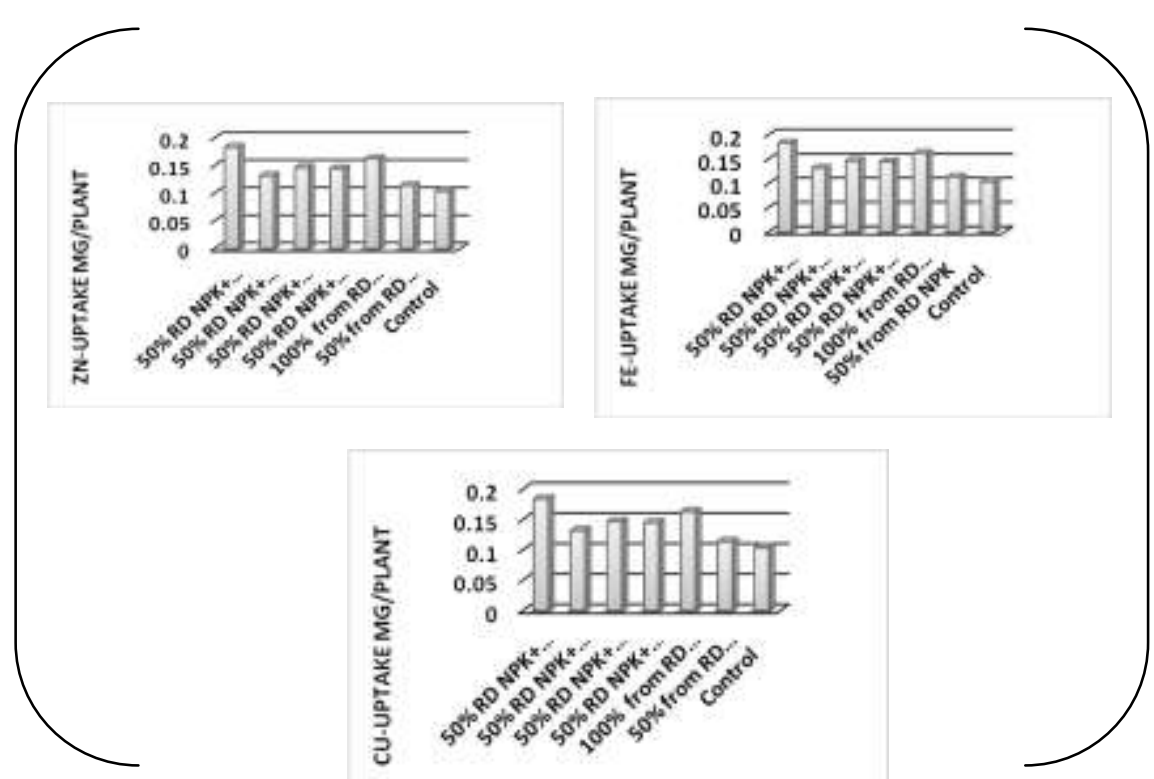

Fig.2. Zinc, iron and copper uptake (mg/plant) as affected by NPK application and some micronutrient

Egypt. J. Soil Sci. 56, No.3 (2016) 
Contents of nitrate, nitrite and nitrate reductase activity in onion bulb were recorded in Table 5. Nitrate concentration measured in onion extracts ranged from 75.09 to $91.5 \mathrm{mg}$ $\mathrm{kg}^{-1}$ of fresh weight. The highest level of nitrate 91.5 was observed in extracts treated with $100 \%$ from RD comparing with other treatments and the lowest value was recorded with the untreated plants. MAFF (1987) reported that nitrate contents in vegetable crops vary enormously, ranging from 1 to $1000 \mathrm{mg} \mathrm{kg}^{-1}$ of fresh weight. According to this classification onion belongs to division I; crops containing low nitrate concentration (> 250 $\mathrm{mg} \mathrm{kg}^{-1}$ ) of fresh weight.

On the other hand, nitrite concentrations ranged from 0.76 to $1.5 \mathrm{mg} \mathrm{kg}^{-1}$. Plants contained the highest value $\left(1.5 \mathrm{mg} \mathrm{kg}^{-1}\right)$ when treated with $100 \% \mathrm{NPK}$ from RD and gave the lowest level of accumulation when treated with the untreated plants. These levels were in the safe extent $\left(10 \mathrm{mg} \mathrm{kg}^{-1} \mathrm{FW}\right)$ and do not cause any toxic effects. As for nitrate reductase activity recorded the highest mean values with $50 \% \mathrm{RD}$ plus $(\mathrm{Fe}+\mathrm{Zn}+\mathrm{Cu})$ comparing with using $100 \%$ NPK from RD which recorded the lowest values. The results are in good agreement with those reported by Zaki et al. (2014) was observed that high accumulation of nitrate and nitrite was observed in extracts of both cultivars when treated with $100 \% \mathrm{RD}$ while, treatments with $50 \% \mathrm{RD}$ decreased the contents of nitrate and nitrite.

TABLE 5. Nitrate, nitrite and nitrate reductase activity as affected by NPK application and some micronutrients

\begin{tabular}{|c|c|c|c|}
\hline Treatments & $\begin{array}{c}\mathrm{NO}_{3}-\mathrm{N} \\
\left(\mathrm{mg} \mathrm{kg}^{-1}\right)\end{array}$ & $\begin{array}{c}\mathrm{NO}_{2}-\mathrm{N} \\
\left(\mathrm{mg} \mathrm{kg}^{-1}\right)\end{array}$ & $\begin{array}{c}\text { Nitrate reductase } \\
\text { activity } \\
\left(\mathrm{mg} \mathrm{min}^{-1} \mathrm{~g}^{-1} \mathrm{FW}\right)\end{array}$ \\
\hline Control & $75.06 \mathrm{~g}$ & $0.76 \mathrm{~g}$ & $1.91 \mathrm{a}$ \\
\hline $50 \%$ from RD of NPK & $89.53 b$ & $1.37 \mathrm{~d}$ & $1.14 \mathrm{f}$ \\
\hline $100 \%$ from RD of NPK & $91.50 \mathrm{a}$ & $1.50 \mathrm{a}$ & $0.99 \mathrm{~g}$ \\
\hline $50 \%$ from $\mathrm{RD}$ of $\mathrm{NPK}+\mathrm{Fe} 300 \mathrm{ppm}$ & $80.40 \mathrm{e}$ & $0.99 \mathrm{e}$ & $1.66 \mathrm{c}$ \\
\hline $50 \%$ from $\mathrm{RD}$ of $\mathrm{NPK}+\mathrm{Cu} 50 \mathrm{ppm}$ & $86.60 \mathrm{c}$ & $1.28 \mathrm{c}$ & $1.33 \mathrm{e}$ \\
\hline $50 \%$ from RD of NPK+ Zn $100 \mathrm{ppm}$ & $83.93 \mathrm{~d}$ & $1.14 \mathrm{~d}$ & $1.48 \mathrm{~d}$ \\
\hline $\begin{array}{l}50 \% \text { from } \mathrm{RD} \text { of } \mathrm{NPK}+(\mathrm{Fe}+\mathrm{Zn}+ \\
\mathrm{Cu})\end{array}$ & $76.40 f$ & $0.83 \mathrm{f}$ & $1.86 \mathrm{~b}$ \\
\hline $\mathbf{L S D}_{\text {at } 5 \%}$ & 1.69 & 0.07 & 0.11 \\
\hline
\end{tabular}

The effect of different treatments was found significant effect on soil available N, P and $\mathrm{K}$ after harvest of onion (Table 6). The significantly highest available $\mathrm{N}, \mathrm{P}$ and $\mathrm{K}$ (70, 10.1 and $\left.277.1 \mathrm{mg} \mathrm{L}^{-1}\right)$ were recorded by treatment $50 \%$ from $\mathrm{RD}$ of $\mathrm{NPK}+(\mathrm{Fe}+\mathrm{Zn}+$ $\mathrm{Cu}$ ) comparing with the control which recorded the lowest values. Increased availabilities of $\mathrm{N}, \mathrm{P}$, and $\mathrm{K}$ may also result from changes in soil nutrient turnover rates due to altered ecosystem properties. Soil nutrient turnover rate consist of decomposition, mineralization, weathering, chemical complexation, adsorption or nutrient uptake by crops and soil organisms (Marrs, 1993). The results are in good agreement with those reported by

Egypt. J. Soil Sci. 56, No.3 (2016) 
Kamble and Kathmale (2015) they found that the significantly highest available nitrogen $\left(213 \mathrm{~kg} \mathrm{ha}^{-1}\right)$, phosphorus $\left(14.42 \mathrm{~kg} \mathrm{ha}^{-1}\right)$ were recorded in $125 \%$ recommended dose of NPK to onion appears to be improving soil fertility.

TABLE 6. Soil availability of N, P and $K$ as affected by NPK application and some micronutrient

\begin{tabular}{|c|c|c|c|}
\hline Treatments & $\begin{array}{c}\begin{array}{c}\text { Nitrogen } \\
\left(\mathrm{mg} \mathrm{L}^{-1}\right)\end{array} \\
\end{array}$ & $\begin{array}{c}\text { Phosphorus } \\
\left(\mathrm{mg} \mathrm{L}^{-1}\right)\end{array}$ & $\begin{array}{c}\begin{array}{c}\text { Potassium } \\
\left(\mathrm{mg} \mathrm{L}^{-1}\right)\end{array} \\
\end{array}$ \\
\hline Control & $45.3 \mathrm{~g}$ & $4.3 \mathrm{~g}$ & $172.5 \mathrm{~g}$ \\
\hline $50 \%$ from RD of NPK & $47.5 \mathrm{f}$ & $5.1 \mathrm{e}$ & $189.3 \mathrm{f}$ \\
\hline $100 \%$ from RD of NPK & $64.5 b$ & $10.0 \mathrm{a}$ & $260.9 b$ \\
\hline $50 \%$ from RD of NPK+ Fe $300 \mathrm{ppm}$ & $60.7 \mathrm{c}$ & $8.0 \mathrm{~b}$ & $239.5 \mathrm{c}$ \\
\hline $50 \%$ from $\mathrm{RD}$ of $\mathrm{NPK}+\mathrm{Cu} 50 \mathrm{ppm}$ & $52.0 \mathrm{e}$ & $6.1 d$ & $209.4 \mathrm{e}$ \\
\hline $50 \%$ from RD of NPK+ Zn $100 \mathrm{ppm}$ & $55.6 \mathrm{~d}$ & $7.0 \mathrm{c}$ & $228.7 d$ \\
\hline $50 \%$ from $\mathrm{RD}$ of $\mathrm{NPK}+(\mathrm{Fe}+\mathrm{Zn}+\mathrm{Cu})$ & $70.0 \mathrm{a}$ & $10.1 \mathrm{a}$ & $277.1 \mathrm{a}$ \\
\hline LSD at $5 \%$ & 3.08 & 0.25 & 5.56 \\
\hline
\end{tabular}

\section{Conclusion}

NPK and some micronutrients $(\mathrm{Fe}+\mathrm{Zn}+\mathrm{Cu})$ can be used in field to enhance the crop nutrient absorption and to have a good quality of onion and decrease accumulation of nitrate and nitrite. It can be concluded that using 50\% NPK from recommended dose and mixture of micronutrients $(\mathrm{Fe}+\mathrm{Zn}+\mathrm{Cu})$ influenced the economic yield and high quality of onion plant.

\section{References}

Alam, M. N., Abedin, M. J. and Azad, M. A. K. (2010) Effect of micronutrients on growth and yield of onion under calcareous soil environment. Inter. Res. J. Plant Sci., 1(3), 056-061.

Alkaff, H. A. and Hassan, A. A. (2003) Effect of biofertilizer, organic fertilizer and foliar application of power 4 on the growth and yield of okra plants. J. Natu. and Appl. Sci., 7(2), 2535 .

Baddour, A. G. (2014) Ecological study on potato and onion crops grown under organic farming comparing with mineral fertilization. Thesis Ph.D. Fac. Agric. Mans. Univ., Egypt.

Bose, U. S., Bisen, A. Sharma, R. K. and Dongre, R. (2009) Effect of micro nutrients along with growth regulator on growth and yield of onion. Inter. J. Appl. Agric. Res., 4 (3), 267-271.

Central Agency for Public Mobilization and Statistics (CAPMS) of ARE (2000) Annual Year Book for General Statistics. Egypt. 
Diriba-Shiferaw, G., Nigussie-Dechassa, R., Kebede, W., Getachew, T. and Sharma, J. J. (2014) Bulb quality of Garlic (Allium sativum L.) as influenced by the application of inorganic fertilizers. African J. Agric. Res. 9 (8), 778-790.

Durgude, A. G., Palwe, C. R., Sawale, D. D. and Kadam, S. R. (2013) Response of onion to soil and foliar application of iron on entisols. The Asian J. Horti. 8,754-757.

El Dardiry, I. E., Abd El-Hady, M., Abou El Kheir, M. S. A. and Abo Ellil, A. A. (2015) Effect of organic manure sources and NPK fertilizer on yield and water productivity of onion (Allium cepa L.). Global Advan. Res. J. Agric. Sci., 4, 803-808.

El Desuki, M. and Sawan, O. M. M. (2001) Effect of mineral fertilizers and sulphur application on growth, yield and quality of onion bulb. Annals of Agric. Sci., Moshtohor, Egypt, 39(1), 617-628.

El Gamelli, H. E. (2000) The effect of some foliar fertilizers application on growth, bulb yield, quality and storage ability of Giza 20 onion cultivar (Allium capa L). Annals of Agric. Sci., Moshtohor, Egypt. 38, 1727-1737.

El Tohamy, W. A., Khalid, A. K., El Abagy, H. M. and Abou Hussein, S. D. (2009) Essential oil, growth and yield of onion (Allium cepa L.) in response to foliar application of some micronutrients. Australian J. Basic and Applied Sci. 3, 201-205.

Fageria, N. K., Filhoa, M. P. B., Moreirab, A. and Guimaresa, C. M. (2009) Foliar fertilization of crop plants. J. Plant Nutr. 32 (6), 1044 S. D. -1064.

FAO, Food and Agricultural Organization (2006) Stadistics Division. Datosagri'colas de FAOSTAT. http://faostat.fao.org.

Gomez, K. A. and Gomez, A. A. (1984) "Statistical Procedures for Agricultural Research" John Wiley and Sons, Inc., New York.pp:680.

Jilani, A. M. S., Khaliq, G. and Waseem, K. (2003) Effect of different NPK levels on the growth and yield of three onion (Allium cepa L.) varieties. Asian J. Plant Sci., 2(3), 342-346.

Kamble, B. M. and Kathmale, D. K. (2014) Effect of different levels of customized fertilizer on soil nutrient availability, yield and economics of onion. J. Appl. and Natural Sci., 7 (2), 817 821.

Kamel, K. A. (2001) Influence of filter mud cake, elemental sulphur applications and micronutrients fertilization on yield and nutrient content of onion. Assuit J. Agric. Sci., 32(5), $105-120$.

Kandil, A. A., Ali, Sh. E. and Fathalla, F. H. (2013) Effect of organic and mineral fertilizers on vegetative growth, bulb yield and quality of onion cultivars. E Sci. J. Crop Prod. 2 (3), 91-100

Kumpulainen, I., Raittila, A. M., Lehto, I. and Koivistoinen, P. (1983) Electro thermal Atomic Absorbtion spectrometric determination of heavy metals in foods and diets. J. Associ. of. Anal. Chem., 66, 1129-1135.

Egypt. J. Soil Sci. 56, No.3 (2016) 
MAFF. (1987) Nitrate, nitrite and N-nitroso compounds in foods. $20^{\text {th }}$ Report of the Steering Group on Food Surveillance, paper No., 20 HMSO, London, UK.

Marrs, R. H. (1993) Soil fertility and nature conservation in Europe: theoretical considerations and practical management solutions. Advan. in Ecological Res., 24, 241-300.

Mertens, D. (2005a) AOAC official method 975.03. Metal in Plants and Pet Foods. Official Methods of Analysis, $18^{\text {th }}$ ed. North Frederick Avenue, Gaitherburg, Maryland, pp. 3-4.

Mertens, D. (2005b) AOAC Official method 975.03. Metal in Plants and Pet Foods. Official Methods of Analysis, 18th ed. North Frederick Avenue, Gaitherburg, Maryland, pp. 3-4

Mishra, P., Sarkar, C., Viswajith, K. P., Dhekale, B.S. and Sahu, P. K. (2013) Instability and forecasting using ARIMA model in area, production and productivity of onion in India, $J$. Crop Weed, 9, 96-101.

Scott, T. (2007) What is the chemical process that causes my eyes to tear when I peel an onion? Ask the expert; Chemistry Scientific American, Retrieved on $8^{\text {th }}$ April, 2007.

Shaheen, A. M., Abdel Mouty, M. M., Ali, A. H. and Rizk, F. A. (2007) Natural and chemical phosphorus fertilizers as affected onion plant growth, bulbs yield and its some physical and chemical properties. Australian J. Basic and Applied Sci., 1, 519-524.

Sharma, R.P. (1992) Effect of planting material, nitrogen and potash on bulb yield of rainy season onion (Allium cepa L.). Indian J. of Agronomy, 37, 868-869.

Singh, A. and Ram, R.B. (2015) Estimation of yield and nutrient uptake by onion under the influence of inorganic, organic and bio-fertilizers. Asian J. Bio. Sci. 10 (2), 129-132.

Singh, J. P. (1988) A rapid method for determination of nitrate in soil and plant extracts. Plant and Soil, 110, 137-139.

Umma, H. (2012) Response of onion to different micronutrients. Thesis M.Sc. Dep. Hort., Bangladesh Agric. Univ. Mymensingh, Bangladesh.

Van Reeuwijk, L. P. (2002) Procedures for Soil Analysis. Inter. Soil Ref. and Info. Centre (ISRIC). Food and Agric. Org. of the United Nations, $6^{\text {th }}$ ed., Wageningen, The Netherlands.

Yaso, I. A. and Abdel-Razzak, H. S. (2007) Effect of NPK fertilization on bulb yield and quality of onion under reclaimed calcareous soil conditions. J. Agric. \& Env. Sci. Alex. Univ., Egypt. 6 (1), 225-244.

Zaki, H. E. M., Toney, H. S. H. and AbdEl Raouf, R. M. (2014) Response of two garlic cultivars (Allium sativum L.) to inorganic and organic fertilization. Nature and Sci., 12(10), 5260 .

(Received: 29/9/2016;

accepted: 27/11/2016) 


\title{
استجابه محصول البصل وتركيبه الكيماوى للتسميا المعنى مع المع الرش بيعض العناصر الصغرى وتركي

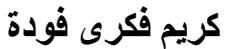

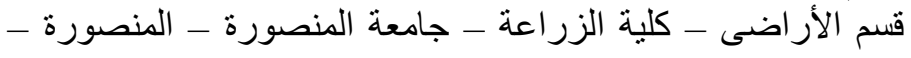

\begin{abstract}
اجريت دراسه حقليه فى المزرعه الخاصه بكليه الزراعه - جامعاته المنصوره

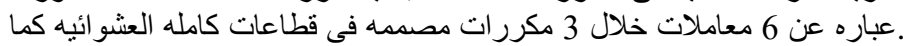

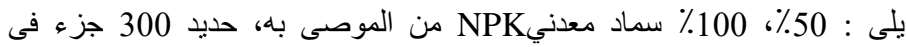

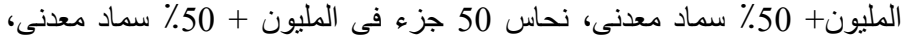
زنك 100 جزء فى المليون + 50٪ سماد معدنى، خليط من العناصر الصغرى

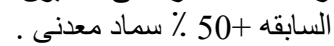

اوضحت النتائج ان جميع المعاملات تحت الدراسه اثرت معنويا فى جميع

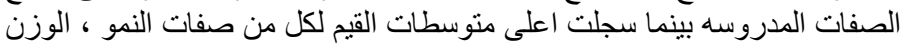

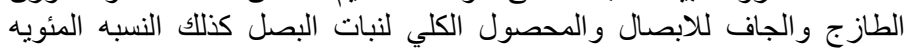

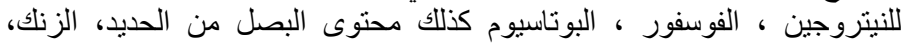

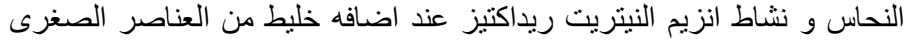

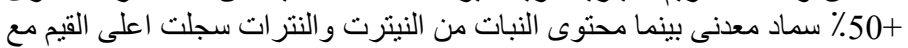

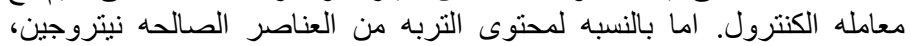

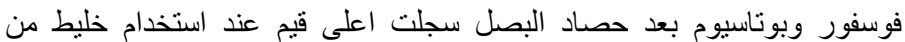
العناصر الصغرى +50٪ سماد معدنى من الموصي به.
\end{abstract}

